anbefale til alle, der beskæftiger sig med konflikter og de svære spørgsmål om forsoning, der rejser sig i forbindelse med konfliktløsning.

JOHAN CHRISTIAN NORD

\section{Korsdrager hinsides godt og ondt...}

Heinrich Detering: Der Antichrist und der Gekreuzigte - Friedrich Nietzsches letzte Texte, Wallstein Verlag, 2010 , 232 sider, $19.90 €$.

Den vidtfavnende og myreflittige germanist Heinrich Detering har begået en lille bog. En lille bog med et omfattende ærinde. Litteraten har sat sig for på litteraturvidenskabelige præmisser at udgrunde den selvbestaltede gudsmorders vej mod forklarelse, kors og guddommeliggørelse: at afdække den altafgørende men ikke desto mindre i reglen upåagtede og negligerede bevægelse i Friedrich Nietzsches sidste tekster; intet mindre end dette har Detering sat sig for.

På bogens første sider formulerer Detering selv anliggendet som "Den Weg zu finden, der von dem Satz "Gott ist todt" zu dem Satz »Gott ist auf der Erde« führte" (s. 10). Altså, en hermeneutisk besindelse på bevægelsen mellem det gale menneskes forkyndelse af Guds død i aforisme 125 i Die fröhliche Wissenschaft og den jubelproklamation af Guds genkomst, som (den gale) Nietzsche i januar 1889 nedfælder i brevform og underskriver med signaturen "Der Gekreuzigte". Et ret så interssant forehavende i en tid, hvor der tales meget om umuligheden af at tilkæmpe sig sådanne kontinuitets- og konsistensorienterede læsninger.

I beskæftigelsen med $\mathrm{Ni}$ etzsches senværk er dette brev til Meta von Salis og de øvrige skrivelser fra tiden umiddelbart før sammenbrudet ofte blevet rubriceret $\mathrm{i}$ overensstemmelse med ovenstående parentetisk indføjede skudsmål - som megalomane produkter af en syfilisbefængt hjerne. Heraf den gængse patologiserende benævnelse Wahnsinnszettel.

Detering anerkender, at $\mathrm{Ni}$ etzsche rent medicinsk meget vel kan have befundet sig i en tilstand af tiltagende mental forstyrrelse, der givetvis kan have indvirket på hans selvidentifikatoriske eskapader, men anerkender ikke, at dette skulle umuliggøre endsige overflødiggøre en reel hermeneutisk besindelse på teksternes udsigelse; i særdeleshed ikke hvis disse udsigelser skulle vise sig at stå i et følgerigtigt forhold til publicerede tekster fra senværket, der - omend kun 
en hårsbredde skiller dem og de patologiserede sedler $\mathrm{i}$ henseende til affattelsestidspunkt - har den ære at blive opfattet som reelle filosofiske arbejder. Og det er netop en sådan tese, der via en minutiøs tekstlæsning, som må opfattes som bogens største styrke, søges eftervist i Deterings kronologisk anlagte undersøgelse. I sine sidste tekster fortæller det subjekt, der ellers havde opløst sig selv, en højdramatisk historie, og Detering vil "die Grammatik dieser Erzählung selbst in den Blick [...] nehmen" (s. 14).

I stærkt kondenseret form lyder argumentet, der sigter mod at afdække en narrativ kohærens på tværs af vanvidsdemarkationslinjen, som følger: I sine sidste tekster tænker Nietzsche i og med figurer. To af disse er Der Antichrist og den frelserskikkelse, som kirken og andre interessenter har så mange navne for. Fra og med det 27. afsnit af Der Antichrist vender Nietzsche - eller netop Der Antichrist, som Detering konsekvent benævner skriftets fortæller - sig mod den navnkundige nazaræer. Men det, der forventedes at være et anklageskrift ender - "Satz für Satz, manchmal Wort für Wort" (s. 34) - som en apologi for den skikkelse, Nietzsche indtil da af al kraft havde draget våben mod. Ingenlunde en apologi for dén svagelige paulinske kors- og soningsteologi, der blev kirkens, men for den »Typus des Erlösers", som "in den Evangelien enthalten sein [könnte] trotz den Evangelien" (KSA 6, 199). I Antikrists Jesusdestillat åbenbarer sig således en tilværelsestydning og livsform, der peger et ganske andet sted hen end den kristelige medlidenhedsmoral; Galilæeren var ikke en nihilistisk fornægter men derimod en verdensvendt forkynder af et modsætnings- og formelløst gudsrige, der i sin radikale nutidighed vender sig imod enhver form for verdensfordobling, idet han udlever det store, milde JA til alle ting. Jesus som tilværelsesbejaelsens prototype par excellence.

Udkommet af dette rekonstruktive indgreb i evangelierne - mod evangelierne - bliver "...das Bild eines gewissermaßen kindlichsanften Bruders des Dionysos" (s. 64), der har overvundet sin egen dekadence og i sin overstrømmende kærlighed til ALT har kappet ethvert bånd til moralen, idet han i sin midlhed lever "diesseits von Gut und Böse" (ibid.).

Fra dette punkt går Deterings næranalytiske argument således slag i slag; over Dionysos-Ditbyramben, hvor overensstemmelsen mellem den syngendes mildhed og skildringen af den korsfæstede livsbejaer peger på en overgang fra voldsfor- 
herligende tragik til mild forklarelse, over Ecce Homo, hvor den skrivende - ifølge Detering i ramme alvor identificerer sig som korsdrager i en gentaget passionshistorie, og til sidst de pseudonyme breve, hvor Antikrist og den korsfæstede er blevet én, hvor Gud atter er på jord og vil denne jord netop som den er.

Det, der står tilbage hos den sene Nietzsche er ikke et dionysisk volds- og magtorgie, men derimod en "Gesammt-Verklärungs-Gefühl aller Dinge (die Seligkeit)" (KSA 6, 207), "eine Sanftmut aus Stärke" (s. 156), hedder det.

\section{Detering tager} kristusidentifikation

Nietzsches alvorligt, meget alvorligt. Velsagtens for alvorligt for nogles smag. Men argumentet er besnærende og dertil vældig stringent og overmåde tekstnært udført; Nietzsche endte i den forklarede mildhed - måske.

Men betyder dette så, at kristendommens selvbestaltede dødsfjende endte som kristen? Ingenlunde, og det postulerer Detering heller ikke. Langt snarere vidner vendingen mod Jesus, hvis altså man tager den besnærende rekonstruktion for gode varer, vel blot om, at også Nietzsche i lighed med så mange andre $i$ den vestlige åndshistorie tilsidst fandt (fremdigtede) sin Jesus, en Jesus der som så mange andres ikke var identisk med den af kirken forkyndte.

Ansporende læsning for den, der kan finde interesse i en litterær kontinuitetsorienteret Nietzschelæsning, og som ikke opfatter en syfilistæret hjerne som en uoverstigelig hindring for en ærlig besindelse på konsistent fortolkningsmæssigt arbejde. Godt udført, det er det, og man kan følgelig kun håbe, at bogen også finder sine danske læsere.

ANDERS DREBY SØRENSEN

\section{Eksistentiel terapi i overblik}
Mick Cooper: Eksisten- tielle terapier, Dansk Psykologisk Forlag, 2011 , 272 sider, 298 kr.

Da filosofi i reglen betragtes som et førvidenskabeligt generaliststudie, og den konventionelle psykoterapi og kliniske psykologi sædvanligt opfattes som en klinisk fagpraksis, er det ikke særligt almindeligt at sammenkoble de to umiddelbart meget heterogene discipliner. Den mest udbredte undtagelse er den eksistentielle terapi, som er en filosofisk terapimetode, der, som en indre rumlen fra 1930erne og frem til i dag, har udfordret det konventionelle psyfaglige kompleks bestående af de fire fagområder: psyko- 